\title{
Synthetic curcuminoid analogues abrogate oxidation- induced cell death and promote myogenic differentiation of C2C12 mouse myoblasts
}

\author{
Chittipong Tipbunjong ${ }^{1 \star}$, Piyawat Sookbangnop ${ }^{2}$, Vachiraporn Ajavakom ${ }^{3}$, \\ Apichart Suksamrarn ${ }^{3}$, Yindee Kitiyanant ${ }^{4}$, Chumpol Pholpramool ${ }^{5}$ \\ ${ }^{1}$ Department of Anatomy, ${ }^{2}$ Department of Biology, Faculty of Science, Prince of Songkla University, Songkhla 90112, \\ ${ }^{3}$ Department of Chemistry and Center of Excellence for Innovation in Chemistry, Faculty of Science, Ramkhamhaeng \\ University, Bangkok 10240, ${ }^{4}$ Department of Anatomy, ${ }^{5}$ Department of Physiology, Faculty of Science, Mahidol University, \\ Bangkok 10400, Thailand
}

*For correspondence: Email: chittipong.t@psu.ac.th; Tel: +66926345297

\begin{abstract}
Purpose: To investigate the ability of two synthetic curcuminoid analogues, 6-(4-hydroxy-3methoxyphenethyl)-5-(3-(4-hydroxy-3-methoxyphenyl)propanoyl)-4-phenyl-3,4-dihydropyrimidin-2(1H)one (compound A) and 6-(4-hydroxy-3-methoxyphenethyl)-4-(4-hydroxy-3-methoxyphenyl)-5-(3-(4hydroxy-3-methoxyphenyl)propanoyl)-3,4-dihydropyrimidin-2(1H)-one (compound B), to protect against oxidation-induced cell death and the potential to enhance proliferation and differentiation of $\mathrm{C2C} 12$ myoblast cells.

Methods: Antioxidant activity of curcuminoid analogues was evaluated by DPPH assay. The cytotoxic activity of the compounds (O-25 mM) on C2C12 myoblasts was determined by MTT assay while the effect on cell proliferation was assessed by BrdU uptake. Myoblast cell differentiation was measured by the formation of myotubes and myosin heavy chain (MHC) protein expression using immunofluorescence staining and Western blotting, respectively.

Results: Both curcuminoid analogues exhibited strong anti-oxidant activity of up to 3-fold greater than that of ascorbic acid, and were non-toxic to C2C12 myoblasts at concentrations up to $25 \mathrm{mM}$. Furthermore, these curcuminoid analogues mitigated myoblast cell death induced by oxidative stress. Notably, both analogues $(10 \mathrm{nM})$ had no effect on cell proliferation. However, only compound $A$ significantly enhanced myoblast differentiation comparable to the effects of dihydrotestosterone (1 $\mu \mathrm{M})$ and estradiol (10 $\mathrm{nM})$.

Conclusion: The results suggest that compound $A$ may serve as a lead compound for the development of suitable therapeutic agents for muscle injuries and diseases.
\end{abstract}

Keywords: Curcuminoid analogues, Antioxidant, Cell proliferation, Cell differentiation, Myoblasts

This is an Open Access article that uses a funding model which does not charge readers or their institutions for access and distributed under the terms of the Creative Commons Attribution License (http://creativecommons.org/licenses/by/4.0) and the Budapest Open Access Initiative (http://www.budapestopenaccessinitiative.org/read), which permit unrestricted use, distribution, and reproduction in any medium, provided the original work is properly credited.

Tropical Journal of Pharmaceutical Research is indexed by Science Citation Index (SciSearch), Scopus, International Pharmaceutical Abstract, Chemical Abstracts, Embase, Index Copernicus, EBSCO, African Index Medicus, JournalSeek, Journal Citation Reports/Science Edition, Directory of Open Access Journals (DOAJ), African Journal Online, Bioline International, Open-J-Gate and Pharmacy Abstracts

\section{INTRODUCTION}

Skeletal muscle mass and strength are progressively loss with aging leading to the decline in functional ability known as sarcopenia [1]. One of the most important factors that could play a key role in triggering sarcopenia is the oxidative stress. In aging conditions, the 
production of reactive oxygen species (ROS) is enhanced while the anti-oxidative capacity is diminished [2] resulting in cellular oxidative stress critical for cell death. Under this condition, the proliferation and differentiation capacities of satellite cells, which are required for muscle repair and/or regeneration, decrease [1] leading to a gradual decline in muscle mass and function.

The expression of acetylcholinesterase (AChE) involves the regulation of cell proliferation, differentiation and survival. For example, myogenic differentiation of $\mathrm{C} 2 \mathrm{C} 12$ cells is associated with an increased expression of AChE [3]. In addition, an upregulation of AChE has been shown after induction of apoptosis by different types of stimuli in various cells [4]. On the other hand, an overexpression of this enzyme has been shown to affect cell-cycle in differentiating cells [5], inhibit cell proliferation and promote apoptosis [6,7]. Although AChE is not a universal activator of apoptosis, it enhances sensitivity to cell death [6]. In addition, AChE involved with cellular apoptosis by implicating in apoptosome formation in various cell types [8]. Recently, we have synthesized a series of curcuminoid analogues in moderate to good yields and showed that they have an anticholinesterase activity suggesting their potential for therapeutic applications in antineurodegenerative diseases such as Alzheimer's disease [9]. However, other biological properties of these compounds have not yet been investigated.

The purposes of this study were to evaluate the antioxidant property of two synthetic curcuminoid analogues and to investigate their abilities to protect myoblasts against oxidative-induced cell death. Furthermore, the potential of these compounds to enhance myoblast proliferation and differentiation were determined.

\section{EXPERIMENTAL}

\section{Reagents}

Unless otherwise indicated, cell culture reagents were purchased from Gibco (CA, USA) and basic chemical reagents and primary antibody were obtained from Sigma-Aldrich (MO, USA). Mouse monoclonal anti-MHC and Western HRP substrate were from Millipore (MA, USA).

\section{Synthesis of curcuminoid analogues}

Curcuminoid analogues, 6-(4-hydroxy-3methoxyphenethyl)-5-(3-(4-hydroxy-3-

methoxyphenyl)propanoyl)-4-phenyl-3,4-
dihydropyrimidin-2(1H)-one (compound A) and 6(4-hydroxy-3-methoxyphenethyl)-4-(4-hydroxy-3methoxyphenyl)-5-(3-(4-hydroxy-3-

methoxyphenyl)propanoyl)-3,4-dihydropyrimidin$2(1 H)$-one (compound B), were synthesized and characterized as previously described [9]. Their chemical structures are illustrated in Figure 1.

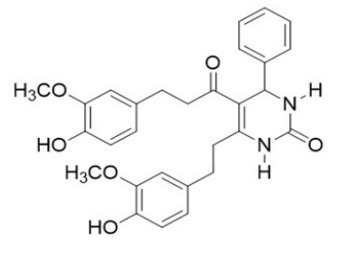

compound A

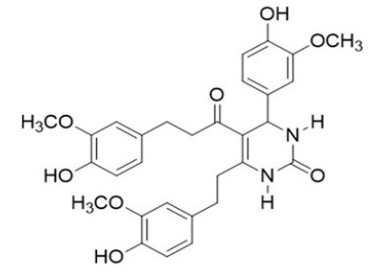

compound B
Figure 1: Chemical structures of synthetic curcuminoid analogues

\section{Cell culture}

C2C12 mouse myoblast cell line was purchased from American Type Culture Collection (VA, USA). Cells were maintained in growth medium (GM; DMEM supplemented with $10 \%$ fetal bovine serum) and $1 \%$ antibiotic at $37^{\circ} \mathrm{C}$ in a humidified $5 \% \mathrm{CO}_{2}$ incubator.

The cell cycle stage of the subconfluence cells were synchronized by being cultured in DMEM for $24 \mathrm{~h}$. The cells were then transferred to GM containing various concentrations of compound $A$ or $\mathrm{B}$ or dihydrotestosterone or $17 \beta$-estradiol for another $24 \mathrm{~h}$. The treated cells were subjected to MTT assay for cytotoxicity and cell proliferation determination.

The confluence cells were cultured in differentiation medium (DMEM supplemented with $2 \%$ horse serum) containing curcuminoid analogues or $17 \beta$-estradiol (E2) or dihydrotestosterone (DHT) for 5 days to stimulate myoblast differentiation. After treatment, differentiated cells were washed and then fixed with cold methanol for immunofluorescence staining or harvested protein for Western blot analysis.

\section{MTT assay}

Cell viability was determined by a reaction with 3-(4,5-dimethylthiazol-2-yl)-2,5-

diphenyltetrazolium bromide (MTT) according to the protocol described previously [10]. The treated cells were incubated with GM containing MTT at $0.5 \mathrm{mg} / \mathrm{mL}$ final concentration for $4 \mathrm{~h}$. Thereafter, the solution was discarded and replaced with $100 \mu \mathrm{L}$ solubilizing solution. 
The absorbance was measured at $570-630 \mathrm{~nm}$ using a microplate reader (BioTek, VT, USA).

\section{DPPH assay}

Free radical scavenging capacity was measured by a reaction with 2,2- diphenyl-1-picrylhydrazyl (DPPH) radical. The aliquots $(100 \mu \mathrm{L})$ of $400 \mu \mathrm{M}$ $\mathrm{DPPH}$ were mixed with various concentrations of $100 \mu \mathrm{L}$ curcuminoid compounds or ascorbic acid in a 96-well plate. Following $30 \mathrm{~min}$ incubation, the absorbance at $517 \mathrm{~nm}$ was measured. Radical scavenging capacity (RSC) was calculated using Equation 1 [11]:

$R S C(\%)=100-\{(A-B) / C\} 100$

where $A$ is the absorbance of the probe; $B$ is the absorbance of the extract alone, and $C$ is the absorbance of the DPPH radical alone. The radical scavenging capacity was shown as $50 \%$ inhibition concentration $\left(\mathrm{IC}_{50}\right)$.

\section{BrdU incorporation assay}

The number of proliferating cells in S-phase was detected by BrdU incorporation assay. At $3 \mathrm{~h}$ before harvested, an aliquot of BrdU solution was directly added into the medium of the treated cells at $10 \mathrm{mM}$ final concentration. The harvesting cells were then fixed with cold methanol for $10 \mathrm{~min}$ before processed to immunofluorescence staining.

\section{Induction of cell death}

C2C12 myoblasts were pretreated with compound $\mathrm{A}$ or $\mathrm{B}$ at the indicated concentration for $24 \mathrm{~h}$. Then, the pretreated cells were transferred to a medium containing $0.8 \mathrm{mM} \mathrm{H}_{2} \mathrm{O}_{2}$ for $24 \mathrm{~h}$ to induce cell death by $80 \%$ [12]. Cell viability was measured by MTT assay as described above.

\section{Immunofluorescence staining}

The fixed cells were washed and rehydrated in PBS. Cells were permeabilized and blocked the nonspecific binding with $5 \%$ normal goat serum diluted in PBS for $1 \mathrm{~h}$. The primary antibody diluted in PBS was applied to cells and then incubated overnight at $4^{\circ} \mathrm{C}$. After several times of washings, cells were incubated with a secondary antibody conjugated with fluorescence dye and Hoechst 33342 for 45 min. The staining signals were visualized under a fluorescence microscope (Olympus IX73; MI, Italy).

\section{Western blotting}

The treated cells were washed and subjected to protein extraction using a RIPA buffer with a protease inhibitor. Protein was separated by centrifugation and then concentration was determined using BCA kit. An equal amount of protein $(20 \mu \mathrm{g})$ was resolved on $10 \%$ SDS-PAGE and transferred to PVDF membrane. To block the nonspecific binding, blots were incubated with $0.5 \%$ skim milk in PBS and were then probed with primary antibody for $1 \mathrm{~h}$ at RT. After severally washed, blots were incubated with appropriate secondary antibody conjugated with HRP. The resulting bands were visualized with Western HRP substrate. The image J software was used to quantify the band intensity.

\section{Statistical analysis}

All data are expressed as a mean \pm standard error of the mean (SEM) of at least three independent experiments. Statistical significance between groups was analyzed by one-way analysis of variance (ANOVA) with Tukey' post hoc test. All statistical analysis were conducted by IBM SPSS version 19 with $p$-value set at ${ }^{*} p<$ $0.05,{ }^{* *} p<0.01$, or ${ }^{* * *} p<0.001$.

\section{RESULTS}

\section{Cytotoxicity and antioxidant activity}

Both curcuminoid analogues at concentrations up to $25 \mu \mathrm{M}$ showed no effect on $\mathrm{C} 2 \mathrm{C} 12$ myoblast cell viability determined by MTT assay. Instead, significant enhancements of cell viability at concentrations lower than $10 \mu \mathrm{M}$ were observed (Table 1). Based on MTT assay which detects the living, but not dead cells, these data indicate that the number of living myoblast cells in curcuminoid treatment groups was increased. Such an increment may be due to enhanced myoblast cell proliferation and/or reduced cell death. BrdU incorporation assay was, therefore, used to detect the proliferating cells during the Sphase.

Table 2: Antioxidant activity of curcuminoid analogues; mean \pm SEM $(n=4)$

\begin{tabular}{ll}
\hline Compound & IC $_{50}(\mu \mathrm{M})$ \\
\hline A & $18.6 \pm 0.1$ \\
B & $17.4 \pm 0.1$ \\
Ascorbic acid & $47.8 \pm 0.1$ \\
\hline
\end{tabular}


Table 1: Cytotoxicity of curcuminoid analogues; mean \pm SEM $(n=4)$

\begin{tabular}{|c|c|c|c|c|c|c|c|}
\hline \multirow{2}{*}{ Compound } & \multicolumn{7}{|c|}{ Percent control at the specified concentration $(\mu \mathrm{M})$} \\
\hline & Control & 0.01 & 0.1 & 1 & 5 & 10 & 25 \\
\hline A & $100 \pm 3.3$ & $\begin{array}{c}160.8 \pm \\
7.8^{* * \star}\end{array}$ & $\begin{array}{c}156.1 \pm \\
5.6^{* \star \star}\end{array}$ & $\begin{array}{l}155.3 \pm \\
10.4^{* \star *}\end{array}$ & $\begin{array}{c}136.5 \pm \\
9.2^{*}\end{array}$ & $\begin{array}{c}109.0 \pm \\
3.0\end{array}$ & $\begin{array}{c}106.7 \pm \\
9.1\end{array}$ \\
\hline B & $100 \pm 3.3$ & $\begin{array}{l}145.1 \pm \pm \\
7.1\end{array}$ & $\begin{array}{c}136.4 \pm \\
7.8\end{array}$ & $\begin{array}{c}129.4 \pm \\
6.4\end{array}$ & $\begin{array}{c}125.7 \pm \pm \\
6.1^{*}\end{array}$ & $\begin{array}{c}109.0 \pm \\
3.4\end{array}$ & $\begin{array}{c}108.4 \pm \\
2.5\end{array}$ \\
\hline
\end{tabular}

Since most aromatic ring compounds that exhibit antioxidant activity $[13,14]$ favor cell viability, the antioxidant property of curcuminoid analogues was investigated using the DPPH assay. Indeed, both compounds exhibited a potent antioxidant activity $\left(\mathrm{IC}_{50}\right.$ of $18.6 \pm 0.1$ and $17.4 \pm 0.1 \mu \mathrm{M}$, respectively) when compared to that of ascorbic acid $\left(\mathrm{IC}_{50}\right.$ of $\left.47.8 \pm 0.1 \mu \mathrm{M}\right)$ (Table 2).

\section{C2C12 myoblast cell proliferation}
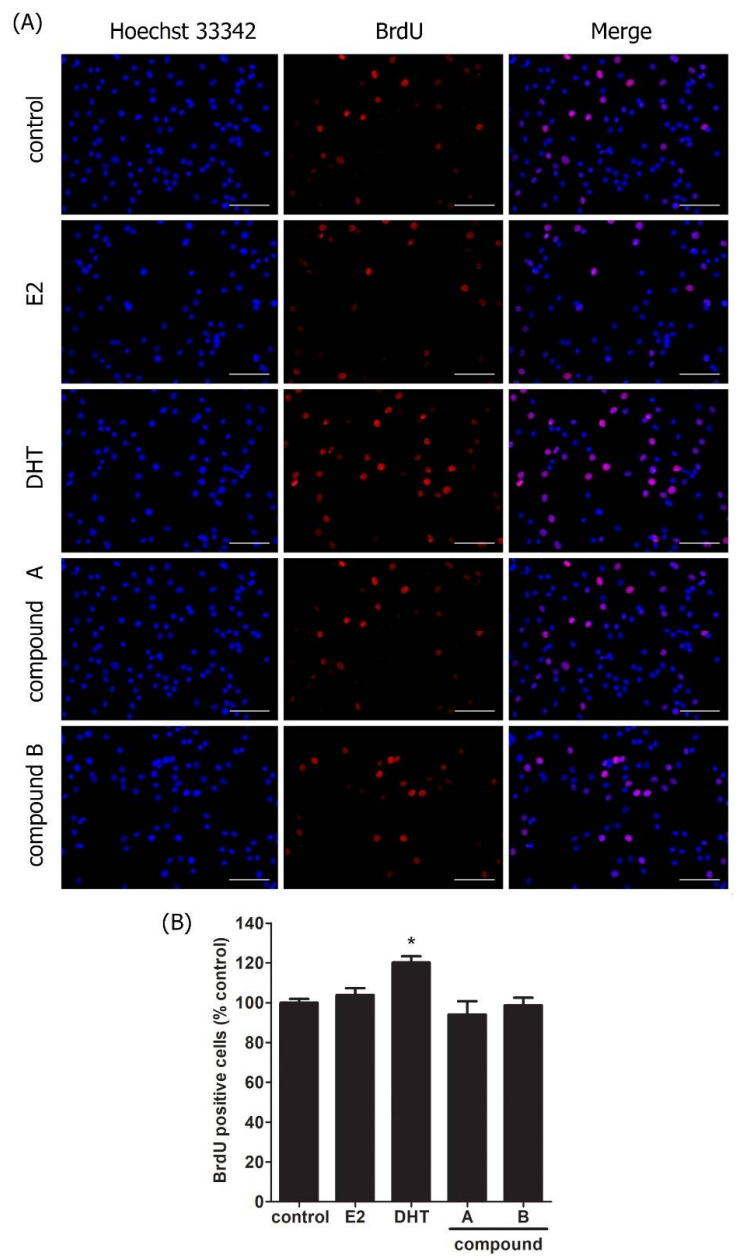

Figure 2: Proliferation of $\mathrm{C} 2 \mathrm{C} 12$ myoblast assessed by $\mathrm{BrdU}$ uptake. (A) Representative photographs of BrdU-positive nuclei (red), BrdU-negative nuclei (blue), and merge (pink) after treatments with curcuminoid analogues (10 nM), E2 (10 nM), or DHT $(1 \mu \mathrm{M})$ for 24 h. (B) Quantitative analysis of BrdU- positive cells expressed as percent of control. Scale bar $=100 \mu \mathrm{m}$

As shown in Table 1, both compounds significantly increased the cell viability at low concentration. This may result from an increase in cell proliferation and/or a decrease in cell death. To delineate these possibilities, BrdU incorporation assay was performed. The results showed that both compounds and E2 did not alter the number of cells in S-phase whereas BrdU uptake was significantly increased the in DHT treatment group (Figure 2). This result suggests that the compounds suppressed cell death but not enhanced cell proliferation.

\section{Protective activity on cell death}

(A)

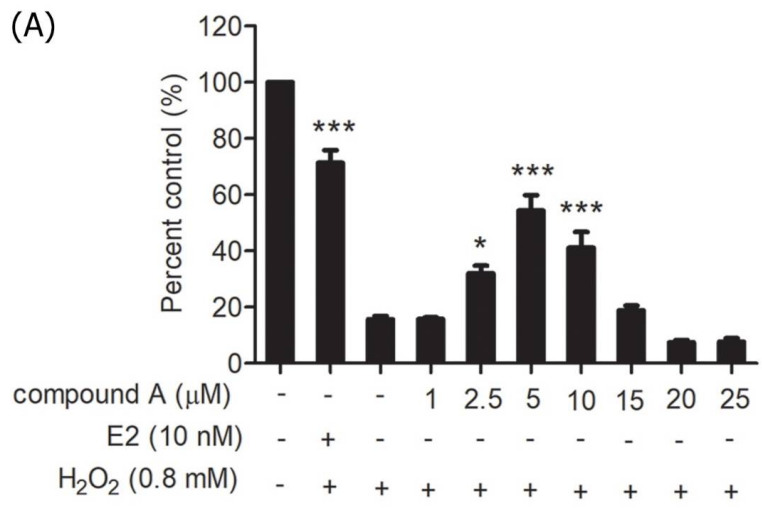

(B)

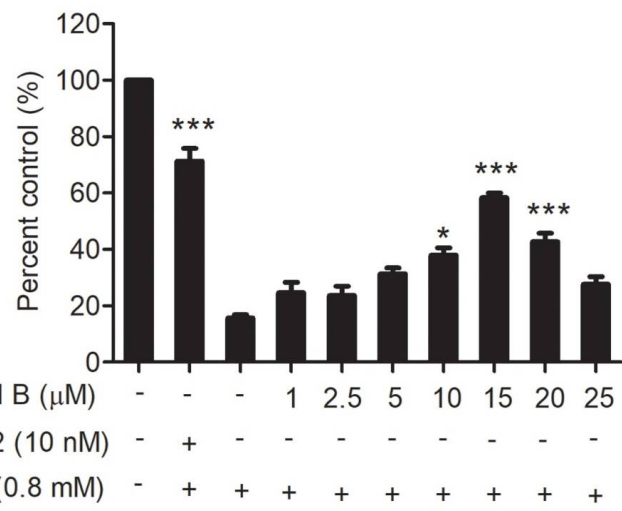

Figure 3: Protective effect of curcuminoid analogues on $\mathrm{H}_{2} \mathrm{O}_{2}$ toxicity in $\mathrm{C} 2 \mathrm{C} 12$ cells. The ability of compound $\mathrm{A}(\mathrm{A})$ and compound $\mathrm{B}(\mathrm{B})$ to prevent cell death induced by $\mathrm{H}_{2} \mathrm{O}_{2}$ 
Oxidative stress is a risk factor for the development of apoptosis and inflammation during muscle regeneration. Anti-oxidation is therefore the key mechanism for preventing those and for improving muscle regeneration efficiency. Our results showed that pretreatment with compound $\mathrm{A}$ and compound $\mathrm{B}$, at concentration 5 and $15 \mu \mathrm{M}$, respectively, significantly mitigated $\mathrm{C} 2 \mathrm{C} 12$ cell death induced by $0.8 \mathrm{mM} \mathrm{H}_{2} \mathrm{O}_{2}$ up to $60 \%$ compared to $75 \%$ in E2 pretreated group (Figure 3 ). This suggests ROS scavenging action.

\section{C2C12 myoblast cell differentiation}

The confluence cells were induced to differentiate into myotubes in the presence of the test compounds. Results showed that compound $A$, but not compound $B$, significantly enhanced C2C12 myoblast differentiation by increasing the numbers and size of myotubes (Figure 4), and $\mathrm{MHC}$ protein expression up to 1.5 folds (Figure $5)$. The enhancement of myoblast differentiation induced by compound $A$ was comparable to those of DHT and E2.

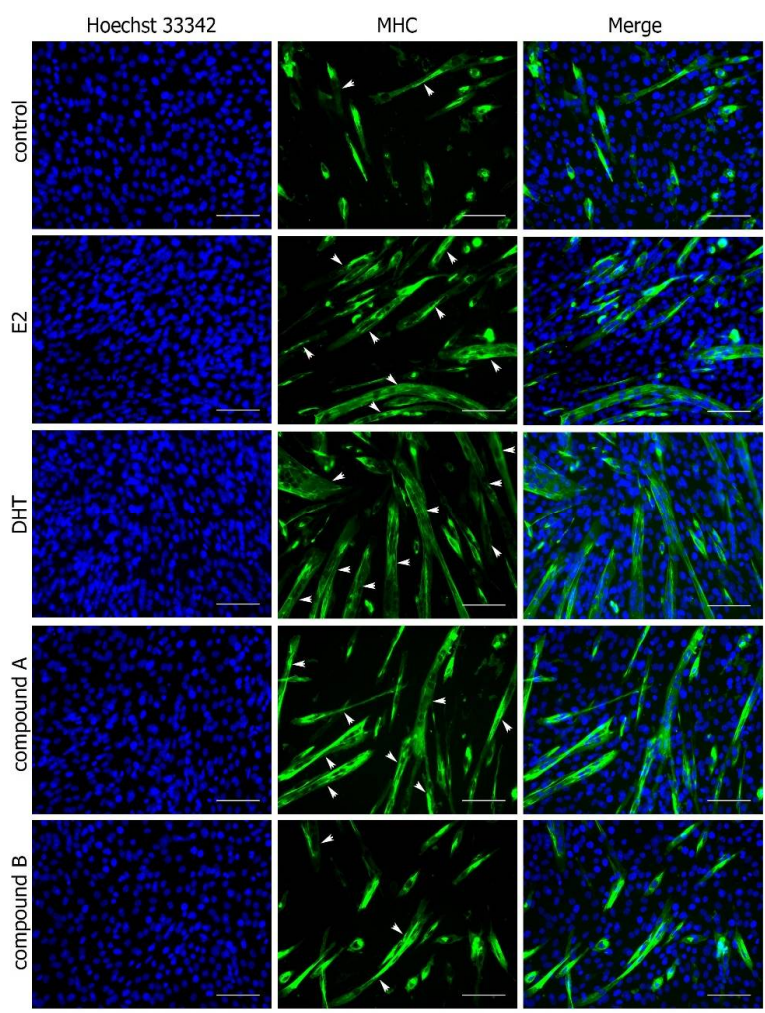

Figure 4: Enhancement of $\mathrm{C} 2 \mathrm{C} 12$ myoblast differentiation by curcuminoid analogues. Representative photographs showing MHC positive myotubes (green, arrowhead) and nuclei (blue) staining after induction of differentiation in the presence of curcuminoid analogues (10 nM), E2 (10 $n M)$, or DHT $(1 \mu \mathrm{M})$ for 5 days. Scale bar $=100 \mu \mathrm{m}$

\section{DISCUSSION}

Our results corroborate those of other studies showing that diarylheptanoids from Curcuma cumosa Roxb are non-cytotoxic to several noncancer cell lines at the concentration lower than $100 \mu \mathrm{M}[13,15-16]$. Similarly, the effects of other diarylheptanoids from other plant species depend on the concentration and/or the cell types being tested [17,18]. Of note, the diarylheptanoids, even from different species, are well-known for antioxidant activity $[13,14]$. Several lines of evidence indicate that the presence of hydroxyl groups on aromatic rings is required for the antioxidant activity. The degree of such activity mainly depends on the numbers and positions of hydroxyls on the nuclear structure. Multiple hydroxyls are favorable for the activity, while mono- and di-hydroxyls exhibit no detectable activity [19].

\section{(A)}

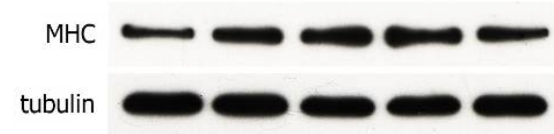

(B)

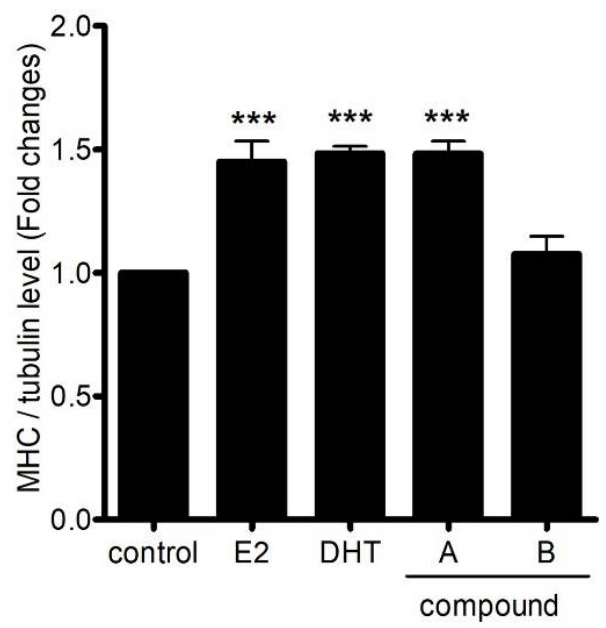

Figure 5: Enhancement of MHC protein expression by curcuminoid analogues. (A) Representative blots of $\mathrm{MHC}$ and tubulin after treatment with each curcuminoid analogue (10 $\mathrm{nM}$ ) compared to E2 (10 $\mathrm{nM})$ and DHT $(1 \mu \mathrm{M})$ for 5 days. (B) Quantitative band intensity of $\mathrm{MHC}$ normalized with tubulin and expressed as fold changes to control

Even though curcumin, a well-known diarylheptanoid, has been reported to stimulate muscle precursor cell proliferation under appropriate conditions [20], only some diarylheptanoid compounds from Curcuma comosa exhibit a proliferative effect on $\mathrm{C} 2 \mathrm{C} 12$ myoblast cells [12]. These compounds also have been shown to promote proliferation in MC3T3E1 mouse pre-osteoblast [15] and human osteoblast cells [16]. Such a variable impact effect on cell proliferation maybe due to the type 
and concentration of compounds, and cell types being tested.

The free radical scavenging occurs through enzyme and non-enzyme mechanisms, the latter takes place through compounds widely present in natural plants. Curcuminoid analogues used in this study has been reported to inhibit acetylcholinesterase activity [9], which is expressed after apoptosis induced by different stimuli [4]. Other diarylheptanoids from different plant species also exhibit a protective effects on cell death induced by different chemicals. For example, acerogenin A from Acer nikoense showed a protective effect against glutamateinduced neurotoxicity in mouse hippocampal HT22 cells [21]. Two other diarylheptanoids from the bark of black alder (Alnus glutinosa) significantly antagonized the effects of doxorubicin-induced cell death in human normal keratinocytes [22]. The current research indicates that diarylheptanoids play a key role in cellular protection against cell death induced through $\mathrm{PI} 3 \mathrm{~K} / \mathrm{Akt}$ and Nrf2 signaling pathways [21]. The results, therefore, confirm previous studies and further illustrate that this activity of the diarylheptanoids is not limited to human retinal epithelial cells, human normal keratinocytes, rat hepatocytes, and mouse hippocampal cells but also extends to mouse myoblasts.

The effect of curcuminoids on myoblast differentiation has been reported to show a biphasic effect. Thus, curcumin at low concentration $(1 \mu \mathrm{M})$ promoted primary mouse myoblast differentiation both in vitro and in vivo studies by increasing MHC level up to 3 -folds [20]. On the other hand, high concentration (20 $\mu \mathrm{M})$ of curcumin significantly inhibited myoblast differentiation by suppressing myogenin and MHC expression [23]. The stimulatory effect of curcuminoids on cell differentiation is not limited only to myoblasts. They also stimulated cell differentiation of MC3T3-E1 mouse preosteoblasts [15] and NB-39 neuroblastoma [17]. The action of curcuminoids on myoblast differentiation is abolished by ICl 182,780, suggesting that curcuminoids enhance myoblast differentiation by activating ER [12]. In addition, curcuminoids also mediate their activity through the ER to enhance differentiation in osteoblasts $[15,16]$. Notably, the results showed that only compound $\mathrm{A}$, but not compound $\mathrm{B}$, enhanced myoblast differentiation. This may be due to its ability to adjust its alignments suitable for ER activation. Of note, curcuminoids possess the biphenolic structure similar to E2, as well as the presence of hydroxyl groups, which is required for binding with ER. Whether or not the effect on myoblast differentiation is involved with binding to ER warrants further investigations.

\section{CONCLUSION}

The findings of this study show that synthetic curcuminoid compound $\mathrm{A}$ and $\mathrm{B}$ are not toxic to C2C12 mouse myoblasts. These compounds also exhibit antioxidant activity that is greater than that of ascorbic acid. Moreover, they mitigate cell death induced by $\mathrm{H}_{2} \mathrm{O}_{2}$. Although both compounds do not enhance cell proliferation, however, compound $\mathrm{A}$ enhances myogenic differentiation of myoblasts comparable to the effects of DHT and E2. Therefore, the ability of compound A to prevent muscle wasting and/or enhance muscle regeneration after injury indicates that it is a potential therapeutic agent for the treatment of muscle injury and/or diseases.

\section{DECLARATIONS}

\section{Acknowledgement}

This work was supported by: The Thailand Research Funds (DBG 5980003); Center of Excellence for Innovation in Chemistry, Office of the Higher Education Commission; Department of Anatomy and Department of Physiology, Faculty of Science, Mahidol University.

\section{Conflict of Interest}

No conflict of interest associated with this work.

\section{Contribution of Authors}

The authors declare that this work was done by the authors named in this article and all liabilities pertaining to claims relating to the content of this article will be borne by them.

\section{REFERENCES}

1. Fulle $S$, Protasi F, Tano GD, Pietrangelo $T$, Beltramin A, Boncompagni S, Vecchiet L, Fanò $G$. The contribution of reactive oxygen species to sarcopenia and muscle ageing. Exp Gerontol 2004; 39(1): 17-24.

2. Fulle $S$, Donna $S D$, Puglielli $C$, Pietrangelo $T$, Beccafico $S$, Bellomo $R$, Protasi F, Fanò G. Age-dependent imbalance of the antioxidative system in human satellite cells. Exp Gerontol 2005; 40(3): 189-197.

3. Siow NL, Choi RC, Cheng AW, Jiang JX, Wan DC, Zhu SQ, Tsim KW. A cyclic AMP-dependent pathway regulates the expression of acetylcholinesterase during myogenic differentiation of C2C12 cells. J Biol Chem 2002; 277(39): 36129-36136. 
4. Zhang $X J$, Yang L, Zhao Q, Caen JP, He HY, Jin $Q H$, Guo LH, Alemany M, Zhang LY, Shi YF. Induction of acetylcholinesterase expression during apoptosis in various cell types.Cell Death Differ 2002; 9(8): 790-800.

5. Inokoshi J, Katagiri M, Arima S, Tanaka H, Hayashi M, Kim YB, Furumai R, Yoshida M, Horinouchi S, Omura $S$. Neuronal differentiation of neuro 2a cells by inhibitors of cell cycle progression, trichostatin $A$ and butyrolactone $I$. Biochem Biophys Res Commun 1999; 256(2): 372-376.

6. Jin $Q H$, He HY, Shi YF, Lu H, Zhang XJ. Overexpression of acetylcholinesterase inhibited cell proliferation and promoted apoptosis in NRK cells. Acta Pharmacol Sin 2004; 25(8): 1013-1021.

7. Cohen JE, Zimmerman G, Melamed-Book N, Friedman $A$, Dori $A$, Soreq $H$. Transgenic inactivation of acetylcholinesterase impairs homeostasis in mouse hippocampal granule cells. Hippocampus 2008; 18(2): 182-192.

8. Park SE, Kim ND, Yoo YH. Acetylcholinesterase plays a pivotal role in apoptosome formation. Cancer Res 2004; 64(8): 2652-2655.

9. Arunkhamkaew $S$, Athipornchai A, Apiratikul $N$, Suksamrarn A, Ajavakom V. Novel racemic tetrahydrocurcuminoid dihydropyrimidinone analogues as potent acetylcholinesterase inhibitors. Bioorganic Med Chem Lett 2013; 23(10): 2880-2882.

10. Mosmann T. Rapid colorimetric assay for cellular growth and survival: Application to proliferation and cytotoxicity assays. J Immunol Methods 1983; 65(1-2): 55-63.

11. Orčić DZ, Mimica-Dukić NM, Francišković MM, Petrović SS, Jovin ED. Antioxidant activity relationship of phenolic compounds in Hypericum perforatum L. Chem Cent J 2011; 5: 34.

12. Tipbunjong $C$, Kitiyanant $Y$, Chaturapanich $G$, Sornkaew $N$, Suksamrarn A, Kitiyanant N, Esser KA, Pholpramool C. Natural diarylheptanoid compounds from Curcuma comosa Roxb. promote differentiation of mouse myoblasts C2C12 cells selectively via ER alpha receptors. Med Chem Res 2017; 26(1): 274-286.

13. Jitsanong $T$, Khanobdee $K$, Piyachaturawat $P$, Wongprasert K. Diarylheptanoid 7-(3,4 dihydroxyphenyl)-5-hydroxy-1-phenyl-(1E)-1-heptene from Curcuma comosa Roxb. protects retinal pigment epithelial cells against oxidative stress-induced cell death. Toxicol In Vitro 2011; 25(1): 167-176.

14. Riethmüller E, Tóth G, Alberti Á, Végh K, Burlini I, Könczöl Á, Balogh GT, Kéry Á. First characterisation of flavonoid-and diarylheptanoid-type antioxidant phenolics in Corylus maxima by HPLC-DAD-ESI-MS. J Pharm Biomed Anal 2015; 107: 159-167.
15. Bhukhai K, Suksen K, Bhummaphan N, Janjorn K, Thongon $N$, Tantikanlayaporn $D$, Piyachaturawa $P$, Suksamrarn S, Chairoungdua A. A phytoestrogen diary/heptanoid mediates estrogen receptor/Akt/ glycogen synthase kinase 3beta protein-dependent activation of the Wnt/beta-catenin signaling pathway. $J$ Biol Chem 2012; 287(43): 36168-36178.

16. Tantikanlayaporn $D$, Robinson LJ, Suksamrarn $A$, Piyachaturawat $P$, Blair HC. A diarylheptanoid phytoestrogen from Curcuma comosa, 1,7-diphenyl-4,6heptadien-3-ol, accelerates human osteoblast proliferation and differentiation. Phytomedicine 2013; 20(8-9): 676-682.

17. Tabata K, Yamazaki Y, Okada M, Fukumura K, Shimada A, Sun $Y$, Yasukawa K, Suzuki T. Diarylheptanoids derived from Alpinia officinarum induce apoptosis, $S$ phase arrest and differentiation in human neuroblastoma cells. Anticancer Res 2009; 29(12): 4981-4988.

18. Uto T, Tung NH, Appiah-Opong R, Aning A, Morinaga O, Edoh D, Nyarko AK, Shoyama Y. Antiproliferative and pro-apoptotic activity of diarylheptanoids isolated from the bark of Alnus japonica in human leukemia cell lines. Am J Chin Med 2015; 43(4): 757-767.

19. Lin CZ, Zhu CC, Hu M, Wu AZ, Bairu ZD, Kangsa SQ. Structure-activity relationships of antioxidant activity in vitro about flavonoids isolated from Pyrethrum tatsienense. J Intercul Ethnopharmacol 2014; 3(3): 123127.

20. Thaloor D, Miller KJ, Gephart J, Mitchell PO, Pavlath GK. Systemic administration of the NF-kappaB inhibitor curcumin stimulates muscle regeneration after traumatic injury. Am J Physiol 1999; 277(2): 320-329.

21. Lee DS, Cha BY, Woo JT, Kim YC, Jang JH. Acerogenin A from Acer nikoense Maxim prevents oxidative stress-induced neuronal cell death through Nrf mediated heme oxygenase-1 expression in mouse hippocampal HT22 cell line. Molecules 2015; 20(7): 12545-12557.

22. Dinić J, Ranđelović T, Stanković T, Dragoj M, Isakovic A, Novaković $M$, Pešić $M$. Chemo-protective and regenerative effects of diarylheptanoids from the bark of black alder (Alnus glutinosa) in human normal keratinocytes. Fitoterapia 2015; 105: 169-176.

23. Hamed M, Khilji S, Chen J, Li Q. Stepwise acetyltransferase association and histone acetylation at the Myod1 locus during myogenic differentiation. Sci Rep 2013; 3: 2390. 